\title{
Implications of Narrative Unreliability in Kazuo Ishiguro's The Remains of the Day
}

\section{Kazuo Ishiguro’nun Günden Kalanlar Romanında Anlatı Güvenilmezliğinin Çıkarımları} Elif TOPRAK SAKIZ*

\begin{abstract}
The objective of this study is to analyse the predominating narrative unreliability in Kazuo Ishiguro's The Remains of the Day (1989) within the framework of rhetorical narratology with a specific focus upon the notion of subjectivity. The homodiegetic narrator, the ageing butler Stevens, is far from fitting unproblematically into the definition of unreliable narrator. The exploration of the employment of narrative unreliability in the novel must, therefore, be aligned with central themes like the national identity and Englishness precisely because it is through Stevens's narration that these grand narratives can be revealed as fiction. What is at issue in the novel is also the very act of narration itself, which is problematized as evasive, nonauthoritative, repressed, and obfuscating. Stevens's narration is profoundly retrospective, looking backwards not only to retrieve the past memories of 'great' days in the service of Lord Darlington, but also to base his own subjectivity upon this 'greatness'. In this respect, by dealing with various functions of the use of an unreliable narrator in The Remains of the Day, it is possible to come up with certain implications of Stevens's unreliability that is rendered manifest by means of evasion or repression of narration, fallibility of memory, and disintegration of subjectivity and national identity.
\end{abstract}

Keywords: unreliable narrator, narrative unreliability, national identity, subjectivity, narrative theory, Kazuo Ishiguro

Öz

Bu çalışmada, Kazuo Ishiguro'nun Günden Kalanlar (1989) romanında hakim olan anlatı güvenilmezliğinin retorik-odaklı anlatıbilim çerçevesinde, özneleşme kavramına odaklanarak incelenmesi amaçlanmaktadır. Romanın iç anlatıcısı, yaşlanmakta olan uşak Stevens, güvenilmez anlatıcı tanımına problemsiz olarak uymaktan çok uzaktır. Bu yüzdendir ki, romanda anlatı güvenilmezliği kullanımı, ulusal kimlik ve İngilizlik gibi temel temalarla bir arada incelenmelidir, çünkü Stevens'ın anlatımı aracılığıyla bunlara benzer üstanlatıların birer kurgu olduğu açığa çıkarılabilmektedir. Romanda tartışılan başka bir konu ise, kaçamaklı, yetkisiz, bastırılmış ve gizleyici olarak sorunsallaştırılan anlatı işinin kendisidir. Stevens'ın anlatımı son derece geriye dönüktür; yanlızca Lord Darlington'un hizmeti altındayken geçen 'muhteşem' günleri yeniden yadetmek için değil, aynı zamanda kendi kimlik anlayışını bu 'muhteşemlik' temeline kurmak için geçmişe bakmaktadır. Bu bağlamda, Günden Kalanlar'da güvenilmez anlatıcıya yer verilmesinin çeşitli işlevleri ele alınarak, anlatının sakınılması veya baskılanması, hafızanın yanılabilirliği ve benlik ile ulusal kimliğin parçalanması yoluyla belirgin hale gelen Stevens'ın güvenilmezliğinin belirli çıkarımlarına ulaşmak mümkündür.

Anahtar Kelimeler: güvenilmez anlatıcı, anlatı güvenilmezliği, ulusal kimlik, özneleşme, anlatı teorisi, Kazuo Ishiguro

\section{Introduction}

Kazuo Ishiguro predominantly employs unreliable narrators in his novels and they serve various functions. The narrator of The Remains of the Day (1989), in particular, constructs his narrative within a multi-layered structure, thereby accommodating hidden meanings within what he seems to be relating. Indeed, his narrative strategy involves overemphasizing quite trivial incidents and details as well as attaching somehow discrepant meanings to certain events. With a close look at his narrative unreliability, his complex relationship with the past and his obsessive use of words like 'greatness' and 'dignity' can be dismantled. Once his basic notions are deeply shaken, Stevens is left without any foundations, any means to draw the sketches of his own subjectivity. Stevens's journey across the country is in fact an epistemological journey where he can no longer remain a stable, ontological

\footnotetext{
* Öğr. Gör., Dokuz Eylül Üniversitesi, Yabancı Diller Yüksekokulu, Yabancı Diller Bölümü, Yabancı Diller Anabilim Dalı, elif.sakiz@deu.edu.tr.
}

Toprak S.E. (2019). Implications of Narrative Unreliability in Kazuo Ishiguro's The Remains of the Day, Gaziantep University Journal of Social Sciences, 18(3), 1050-1057, Submission Date: 10-12-2018, Acceptance Date: 01-07-2019.

Araştırma Makalesi. 
being. Furthermore, it is argued here that Stevens as an unreliable narrator resists straightforward categorization as far as his relationship with the implied author and the implied reader is taken into consideration. Even though the concept of unreliable narrator in the novel has received a good deal of critical attention so far, its implications and underlying meanings are yet to be explored further, which this paper aims to undertake. In this respect, the narrative structure of the novel calls for a multidimensional narratological analysis with recourse to recurrent concepts and terms within the framework of rhetorical narratology.

In The Rhetoric of Fiction (1961), Wayne C. Booth claims that "rhetorical dimension in literature is inescapable" (105), that is using language to persuade and communicate with the reader is a significant occupation in which narrative discourse is as consequential as the narrated actions. The degree of (un)reliability, particularly, is a central aspect of textual analysis within certain approaches to rhetorical narratology, which focuses on the aspects of narration, such as implied author, types of narrator(s), narrative levels, and a number of narrative acts. In a narrative, Phelan argues, "somebody tries to accomplish some purpose(s) by telling somebody else that something happened" ("Rhetoric/Ethics", 2007a, p. 209), which in turn constitutes the discourse of narration. In Seymour Chatman's definitive terms, distance between story (what really happens) and discourse (how the events are recounted by the narrator) is the source of narrative unreliability (1978, p. 233). Rimmon-Kenan (1990) also underlines the ways in which unreliable narration can be detected: "when the facts contradict the narrator's views, the latter is judged to be unreliable" and "when the narrator's language contains internal contradictions, double-edged images, and the like, it may have a boomerang effect, undermining the reliability of its user" (p. 101). In The Remains of the Day, the narrative act is mostly in line with these definitions, involving not only a gap between story and discourse, but also several contradictory verbal practices of the narrator; however, in the end it turns out to be a challenge to such well-delineated definitions of unreliability. In this respect, this paper will follow Kathleen Wall (1994)'s formulation of "new paradigms of unreliability" in the novel (p. 23).

An insight into the concept of the implied author is an indispensible part of defining narrative unreliability. According to Booth, it is "large ironies" that separate the implied author and narrator(s) (73), which results in unreliability. Basing his theory on Booth's, Phelan explicates the reason for unreliability: "[t]he implied author may endorse the narrator's account and evaluation of the events or may establish distance from the narrator's account and evaluation. The endorsement yields reliable narration, and the establishment of distance yields unreliable narration" (Rhetorical Approaches to Narrative, 2005, p. 502). In The Remains of the Day (1989), it is possible to speak initially of such a distance between the implied author and the narrator in that Stevens's account of the events is mostly defective, his evaluation of them misleading. However, this distance comes to narrow down towards the end of the narrative.

James Phelan emphasizes the communicative function of narration: "Rhetorical approaches conceive of narrative as an art of communication" ("Rhetorical Approaches to Narrative", 2005, p. 500). Phelan (2007b)'s categorization of three axes of communication (facts, perception and values) is an efficient tool to differentiate between types of unreliability. The fact that all three aspects are not simultaneously present in unreliability applies well to Stevens's narrative situation. He is at times unreliable in the axis of facts and event as he has no inclination towards misreporting; however, he is unreliable in the other two axes because the way he presents his perceptions, values and judgements is usually misleading, that is he tends to misinterpret or misregard events. These gaps are merely visible in the discourse of the narrative.

The fact that "the implied author is the source of the norms and values communicated 
by the text" (Ryan, 2011, 35) distinguishes him from the real author whose mind is inaccessible. It is through these norms and values that we are, as authorial readers, able to communicate with the implied author. Whether we share them or not determines our relationship with the text. Although sometimes we recognize and agree with the norms and values of the text, at other times we are cognizant of the irony beneath what the narrator claims to be the truth. In this case, the implied readers are separated from the narrator(s) while positing themselves side by side with the implied author. In other words, as Wayne C. Booth claims, a "secret communion" between the reader and the implied author is established behind the narrator's back (1961, p. 300). This kind of relationship is discernible in the novel as long as Stevens sustains his nostalgia for the good old days of England. However, the implied author does not share Stevens's nostalgic engagement with Englishness; therefore, as Shaffer claims, there exists mock nostalgia (2008, p.88).

The real question is what kind of effect unreliability has on the side of the authorial audience? As the audience, do we distance ourselves from the narrator, or do we get closer to each other when we recognize the contradictions in his/her narration? James Phelan (2007b) paves the way for an answer to such a question in his theory of estranging and bonding unreliability. Of these two types of unreliability, estranging unreliability means a distance, or estrangement in the communicative exchange between the narrator and the authorial audience whereas bonding unreliability marks, in an unlike way, reduction of this distance between the participants, as stated by Phelan: "In bonding unreliability, the discrepancies between the narrator's reports, interpretations, or evaluations and the inferences of the authorial audience have the paradoxical result of reducing the interpretive, affective, or ethical distance between the narrator and the authorial audience" (2007b, p. 225). In Stevens's case, it is not easy to make such a straightforward distinction in that as readers, we both feel sympathetic for Stevens's self-delusion and resentful for his unquestioning attachment to essential models of national identity. His unreliability, thus, functions to distance the authorial reader from an essentialist and monolithic idea of Englishness.

Narrators are usually ideologically positioned in their act of narration in spite of their claims to faithfulness to truth. Wall categorizes the implied author's purposes to employ an unreliable narrator. Stevens cannot be categorized as an ordinary unreliable narrator "whose world view, predispositions, ignorance, or absent-mindedness determine in some way what he or she notices, and how he or she interprets certain situations" (Wall, 1994, p. 22). As Wall points out, "an essential indication of the narrator's unreliability is frequently found in the discourse of narration, in the verbal habits of the narrator" (ibid, p. 20). It is necessary, therefore, to take a close look at the textual clues that manifest Stevens as a narrator that is unreliable not on account of unknowingness but due to a strategy to cope with forceful identity-making processes.

Nominating Ishiguro's narrator in The Remains of the Day as a challenging example of unreliability, Kathleen Wall holds that the novel undermines the conventional understanding of unreliable narrator:

$[\mathrm{T}]$ he novel challenges our usual definition of an unreliable narrator as one whose 'norms and values' differ from those of the implied author, and questions the concept of an ironic distance between the mistaken, benighted, biased, or dishonest narrator and the implied author, who, in most models, is seen to communicate with the reader entirely behind the narrator's back. (ibid, p. 18)

Stevens's unreliability stems from his "split subjectivity, rather than moral blindness or intellectual bias" (ibid, p. 23). Thus, the reader's task to get at a fixed, pre-established 'truth' by deciphering the norms of the text is no longer relevant, nor desirable. This could be pertaining to Ishiguro's claim to the status of an international writer, one who appeals to 
transnational audience rather than a 'parochial' perspective (of white English audience) that holds shared norms and values (of Englishness).

\section{The Disintegrated Subjectivity of the Unreliable Narrator}

In poststructuralism, the notion of subjectivity is viewed in linguistic terms. Jacques Derrida (1973), by referring to Saussurean theory, explicates this relationship between language and subjectivity:

That 'language is not a function of the speaking subject'. This implies that the subject (selfidentical or even conscious of self-identity, self-conscious) is inscribed in the language, that he is a 'function' of the language. He becomes a speaking subject only by conforming his speech [...] to the system of linguistic prescriptions taken as the system of differences (1973, p.145$6)$.

The sense of self is thus seen as fragmented because it is constructed only by and in language. Yet, language, as well as the subject within it, is always unstable, inaccessible and incontrollable. There can be viewed, to show an illustration from the novel, a narrational gap where no word regarding the great issues of the world is audible, or present. This gap is characterized by an absence of vocal content in relation to Darlington Hall's great visitors as the reader is provided with an access to their 'speech' only through Stevens's playful writing. Stevens is more comfortable with writing than with speech. Barry Lewis underlines Stevens's uneasy relationship with speech, calling this a 'linguistic mask': "Like a constable in court, Stevens cannot talk with ease because his mouth is full of words" (2000, p. 94). The reason for this is that he is never in control of his own words as they disseminate, even evade, exceed, and transgress their utterer. One characteristic of his elusive language is made manifest in his oscillation between the subjects "I" and "one" in the whole course of his narrative. In certain parts, even as he is recounting his personal acts and feelings, he tends to slip into the subject "one" instead of "I" in an attempt to generalize, or universalize what is personal, or subjective. This is in fact a slippery representation of subjectivity within language. The content of the "I" cannot be fully contained outside, even inside language. This lack of a unified subject who is in control of his own language evinces itself in Stevens's evacuation of "I" and turning it into a slippery, indefinite, and ever-changing "one".

Stevens's narration is characterized by an evasive language, one that tends to distance emotion, belie meaning, and manipulate memory. Adam Parkes claims that "Stevens speaks a language of "silence and elusion"" (2001, p. 60). Evasiveness as a narrative technique is evident in his occasional switches from the pronoun "I" to a more obscure "one" to designate himself. This is to evade emotional involvement or to distance himself from an emotion (Wall, 1994, p. 24). His use of 'one' is an attempt to veil his feelings and divert attention from his real motives to a professional guise, as in the case of his planning to purchase new clothes before he sees Miss Kenton: "it is just that one never knows when one might be obliged to give out that one is from Darlington Hall, and it is important that one be attired at such times in a manner worthy of one's position" (emphasis added; Ishiguro, 1989, p. 11). Likewise, Miss Kenton accuses him of not revealing his disillusionment upon the dismissal of two Jewish maids, and when the emotions are concerned, he gets alarmed of the intimacy of an Isubject, replacing it with 'one': "Naturally, one disapproved of the dismissals" (ibid, p. 162). In another attempt to evade closeness with Kenton, he fails to give his condolences upon her aunt's death, ending up criticizing the new recruits under her supervising. His retrospective narration of the event has an emotionally-detached tone (despite his too late regret) with the use of 'one' in an absurd way:

Naturally, when one looks back to such instances today, they may indeed take the appearance of being crucial, precious moments in one's life; but of course, at the time, this was not the impression one had. 
Rather, it was as though one had available a never-ending number of days, months, years in which to sort out the vagaries of one's relationship with Miss Kenton (emphasis added; ibid, p. 188).

Another evasive word he exploits is "professional," which is used in two situations: to excuse lack of emotion, and to hide his feelings under a professional mask (Wall, 1994, p. 24). He denies to give out the personal dimension in Kenton's letter, claiming that this letter "set[s] off a certain chain of ideas to do with professional matters here at Darlington Hall" and that his undertaking of the trip is merely "a preoccupation with this very same professional matters" (Ishiguro, 1989, p. 5); he similarly claims that his choice of West country (where Kenton is settled) as his destination has "a good professional motive" (ibid, p. 14). Unreliable narration in the novel originates not only from Stevens's fallible memory, for Yugin Teo, but also from "a self who is struggling with his emotions while still insisting on keeping those emotions buried deep below the surface" (ibid, p. 36). This "repression of the personal" and "conflict between the public and the private man" lead to a "fractured" or "split" subjectivity in Stevens's case (Wall, 1994, p. 26).

Stevens's unreliability is manifested in the incompatibility between his actions and his declared motives/excuses for those actions. When he is discovered by Kenton to be reading a sentimental romance, he relates his actual motivation in reading such "invariably absurd" plots to the need to "develop one's command of the English language" (Ishiguro, 1989, p. 176) and their usefulness "in the course of one's normal intercourse with ladies and gentlemen" (ibid, p. 177). Moreover, Stevens attaches quite different meanings to the events that take place, making his reading of events flawed. He misreads Kenton's letter though he rereads it several times, ending up each time in the conviction that she inhabits "an unmistakable nostalgia for Darlington Hall", which is yet not explicitly stated in her letter, rather surmised by Stevens through ambiguous remarks, "rather unrevealing passages", and "distinct hints" (ibid, p. 10). Yet he later admits that he is "unable to be certain of Miss Kenton's desire to rejoin the staff here" (ibid, p. 14) as "she does not at any point in her letter state explicitly her desire" (ibid, p. 50). Obviously, his awareness of his own misapprehending the letter culminates in a close analysis of the phrases in the letter in an attempt to justify his own (mis)interpretation as well as to hide his emotional attachment to her, which is betrayed in his insistence to call her in her maiden name (instead of Mrs Benn).

Stevens has self-consciousness about the fallibility and uncertainty of his memory in the construction of his narrative. Memory is an act of repression, a strategy employed to bring certain aspects of the past to the fore while preserving others in a "latent" narrative, and they can be traced only through "clues", gaps, dislocations, and ambivalent comments (Guth, 1999, p. 131). Stevens refuses to get emotionally involved in his father's death, by foregrounding his professional duty in the international conference. Stevens's unacknowledged feelings are only available through the narrative discourse where others' reactions or words (rather than his own) are more expressive of his emotional disposition: Upon learning about his father's being on the brink of death, he is asked by Mr Cardinal and Lord Darlington several times if he is alright and he seems "unwell", which contradicts his report of his assumedly professional reaction (Ishiguro, 1989, p. 109). He ignores his tears, relating the events of this evening "with large sense of triumph" (ibid, p. 115). Similarly, he looks "unwell" (as observed by Mr Cardinal) upon learning about Kenton's engagement (ibid, p. 231), an event to which he seems to attach no overt emotional significance.

Stevens no longer rests on secure grounds to delineate his identity within the longestablished borders of 'greatness', a concept that has much to do, in his mind, with anything English: English landscape, Great Britain, and 'great' English butlers. His idea of self predominantly relies on his ability to maintain the ideal of "We English" (ibid, p. 44). The doubts cast on Lord Darlington's greatness as an employer inevitably pose a threat to his own 
status of a 'great butler'. Therefore, his narrative of Darlington is always repressive, elusive and defensive. He withholds his narration by declining to explicate what 'nonsense' is ascribed to his employer. When he ultimately divulges the substance of this blame on Darlington as regards his connection with the Nazis and anti-Semitism, he gives no credit to such claims: "It needs to be said too what salacious nonsense it is to claim that Lord Darlington was anti-Semitic, or that he had close association with organizations like the British Union of Fascists. Such claims can only arise from complete ignorance of the sort of gentleman his lordship was" (ibid, p. 145). Stevens's attempts to justify his employer's greatness reveal his anxiety about his own conception of self-identification. The widening gap between what is narrated by Stevens and what is presented as direct discourse in the speech of the characters becomes apparent, especially when Lord Darlington himself reveals his antiSemitic attachments in his actual words: "The world's far too complicated a place now for universal suffrage and such like." [...] People are suffering. Ordinary, decent working people are suffering terribly. Germany and Italy have set their houses in order by acting." His propensity towards fascist ideology becomes obvious when he states that "[1] ook at Germany and Italy, Stevens. See what strong leadership can do if it's allowed to act." (ibid, p. 208). Stevens's aggrandizement of his employer, Lord Darlington, is gradually deconstructed in the course of his diary writing; his lord's supposedly noble aspirations are shown to be a disgrace through Stevens's delayed narration. Even when Stevens aggrandizes his employer in the course of his narration, it later turns out that Lord Darlington is far from being a contributor to the state of peace. In fact, the notion of unreliable narrator can be instrumental in dismantling the whole text.

On a self-contradictory impulse, after this 'nonsense' articulated about Darlington he denies a couple of times having worked for his previous employer, then trying to justify his lying. This also points to his urge to sustain his unified understanding of 'greatness'. He further defends him against the allegations that no Jewish staff can be employed in the house, yet he undermines his own narrative as he relates the dismissal of two Jewish housemaids. His act of justification is partly an attempt to protect his own identity as a butler of a respectable gentleman with 'dignity', which is a key dimension, for Stevens, of subjectivity. Yet, he becomes aware of the deficiency of his definition. This exactly happens when he converses with Harry Smith (when he runs out of gas), who proposes an entirely different definition of 'dignity' in terms of expressing one's opinions freely, and more specifically as opposing Hitler (which Darlington fails to do), thereby collapsing the very foundation of Stevens's selfdefinition (ibid, p. 196). Su argues that it is through the redefinition of the key terms (greatness and dignity) associated with national character that essentialist conception of national identity is rejected in the novel (2002, p. 556). As a whole, as Salman Rushdie contends that "[t]he real story here is that of a man destroyed by the ideas upon which he has built his life" (Rushdie, 2012). With the collapse of all his conceptions, Stevens's sense of subjectivity and national identity is thus menaced and shattered.

The narrative revolves around a journey Stevens takes from his never-departed surrounding within the terrain of Darlington Hall to a distant domain, both physically and epistemologically. Darlington Hall is the site of being in which he assumes a pre-determined, static sense of self primarily because of his descriptive role of 'a good butler', one who is endowed with 'dignity'. He previously adopts a very static notion of being a 'butler': "'dignity' has to do crucially with a butler's ability not to abandon the professional being he inhabits. Lesser butlers will abandon their professional being for the private one at the least provocation" (emphasis added, Ishiguro, 1989, p. 43). His definition of this professional attribute is expressed in ontological terms; this state is 'being', which is stable, unchanging, and absolute. Here in this territory he remains within the confines of metaphysics of presence. 
For Derrida (1976), 'being' is nothing more than a "trace" due to the linguistically constructed nature of the subject: "the sense of being is not a transcendental or trans-epochal signified [...] but already, in a truly unheard of sense, a determined signifying trace" (Derrida, 1976, p. 23). Thus, according to Derridean philosophy, being must be written under erasure as being. On the other hand, the course of Stevens's journey to the country marks the on-going, on-themove process of his subjectivity. In this epistemological journey, his taken for granted notion of 'a good butler' is put into question. Cynthia F. Wong maintains that Stevens "seems excruciatingly aware that his ideals structuring his life in the past no longer hold" (2005, p. 53). All his notions are deconstructed and reconstructed during this journey, which carries him onto a slippery ground of being. He observes that "the surrounding grew unrecognizable and I knew I had gone beyond all previous boundaries" (Ishiguro, 1989, p. 24). This indefinable, unlocatable terrain is the epistemological space where he feels "a slight sense of alarm" (ibid). It is frightening since he no longer clings onto a founding principle to delineate his subjectivity. Therefore, he describes his journey as if "setting sail in a ship" that occurs "when one finally loses sight of the land" (ibid). What he means by losing sight of "the land' is this ground upon which one can depend on for all meaning formation, hence without which the subject is left groundless. Yugin Teo views Stevens's journey as a transformation from a partial presence in the darkness of Darlington Hall to a space where he is more apt for selfdiscovery: "Stevens's exposure to the world outside Darlington Hall reveals the gaps in his life that were not visible within the dimly lit walls of Darlington Hall. Stevens can no longer hide in the shadows and stay 'partially visible' as before" $(2014$, p. 30$)$. In this sense, his journey can be defined as a passage from self-ignorance into self-recognition.

Stevens is no longer self-deluded in the end, recognizing the mistaken nature of his ideals to which he has devoted his whole life. Stevens's analeptic narrative is intertwined with the account of his expedition to the West Country. Consequently, Stevens's literal journey turns out to be an epistemological journey of subjectivity. This is a turning point where Stevens ceases to rest on his previously delineated, deeply rooted foundations, and becomes a subject in the process of making. In Weymouth, at the pier he expresses an awareness with regard to Darlington's mistakes, yet what is more distressing is the fact that "[he] can't even say [he] made [his] own mistakes" as he "trusted [he] was doing something worthwhile" (Ishiguro, 1989, p. 256). Another recognition is his acceptance that "one may have previously -perhaps through a wishful thinking of a professional kind -exaggerated what evidence there was regarding such a desire [of returning to Darlington Hall] on [Miss Kenton's] part" (ibid, p. 149). It is at this point of Stevens's self-recognition that initially established ironic distance between the implied author and narrator narrows (Wall, 1994, p. 37). Therefore, Stevens's unreliable narration is a challenge to the concept of unreliable narrator in that his estrangement from the 'secret communion' between the implied author and the reader is eliminated through his final recognition. Implications of his evasive, repressive and delusory narrative are thus traceable in between the lines with the help of narrative strategies employed by the narrator whose split subjectivity is, in turn, rendered manifest.

\section{References}

Booth, W. C. (1991). The Rhetoric of Fiction. New York: Penguin.

Chatman, S. (1978). Story and Discourse: Narrative Structure in Fiction and Film.

Ithaca: Cornell UP.

Derrida, J. (1973). Difference. Speech and Phenomena and other Essays on Husserl's

Theory of Signs, tr. David B.Allison. Evanston, IL: Northwestern University

Press, 129-60. 
Derrida, J. (1976). Of Grammatology. Trans. Gayatri Chakravorty Spivak. Baltimore and London: The John Hopkins University Press.

Guth, D. (1999). Submerged Narratives in Kazuo Ishiguro's The Remains of the Day. Forum for Modern Language Studies, 35(2), 126-37.

Ishiguro, K. (1989). The Remains of the Day. London: Faber and Faber.

Lewis, B. (2000). Kazuo Ishiguro. Manchester and New York: Manchester University Press.

Parkes, A. (2001). The Remains of the Day: A Reader's Guide. New York and London: Continuum.

Phelan, J. (2005). Rhetorical Approaches to Narrative. Routledge Encyclopedia of Narrative Theory. Eds. David Herman, Manfred Jahn and Marie-Laure Ryan. New York: Routledge, 500-504.

Phelan, J. (2007a). Rhetoric/Ethics. The Cambridge Companion to Narrative. Ed. David Herman. Cambridge: Cambridge UP, 203-216.

Phelan, J. (2007b). Estranging Unreliability, Bonding Unreliability and the Ethics of Lolita, Narrative, 222-38.

Rimmon-Kenan, S. (1990). Narrative Fiction: Contemporary Poetics. London:Routledge.

Rushdie, S. (17 Aug. 2012). Salman Rushdie: rereading of The Remains of the Day by Kazuo Ishiguro. The Guardian. Guardian News and Media Limited. Web.

Ryan, M. L. (2011). Meaning, Intent and the Implied Author. Style 45(1), 29-47.

Shaffer, B. (2008). Understanding Kazuo Ishiguro. Columbia: University of South Caroline Press.

Su, John J. (2002). Refiguring National Character: The Remains of the British Estate Novel. Modern Fiction Studies, 48, 552-80.

Teo, Y. (2014). Kazuo Ishiguro and Memory. Houndmills, Basingstoke, Hamshire: Palgrave Macmillan.

Wall, K. (1994). The Remains of the Day and Its Challenges to Theories of Unreliable Narration. Journal of Narrative Technique, 24, 18-42.

Wong, C. F. (2005). Kazuo Ishiguro. Horndon, Tavistock, Devon: Northcote House Publishers Ltd. 